\title{
4. Politico-strategic reasons
}

\section{INTRODUCTION}

This chapter examines the politico-strategic reasons that inform decisions (not) to refer, which have been given considerable attention in the Europeanization literature. However, the empirical results reveal that this emphasis on politico-strategic reasons is not entirely justified. These reasons account only for a small number of references. The majority of references do not involve strategic motives, but rather involve purely legal considerations and deal with often rather boring and technical legal questions. The findings presented in this chapter corroborate recent empirical studies that downplay strategic explanations. Almost all of the judges interviewed in the three countries did not mention spontaneously that politico-strategic reasons play a role in the decision (not) to refer. ${ }^{1}$ Dutch Supreme Court judges insisted that there are 'no hidden agendas' and 'no strategies', because of the court's neutrality. ${ }^{2}$ One judge stated that 'judges are not politicians; you don't see strategies' - not least because the judiciary is too serious for that. ${ }^{3}$ An Irish judge likewise noted that the courts present their own view of the law and do not engage in politics or hope that a law will be changed as a result of their actions. ${ }^{4}$ Another Irish judge referred to such considerations as cynical. ${ }^{5}$ The limited importance of politico-strategic reasons is unsurprising, given that many legal areas are fairly technical and do not conflict with the essence of the rule of law. Judges noted that most cases do not involve issues of conscience. ${ }^{6}$ One UK judge, for instance, reported that 'we are not too worried' about most cases. ${ }^{7}$ The Dutch highest administrative court judges also maintained that they have no interest in particular outcomes. ${ }^{8}$ Most tax cases, for instance, deal only with money.

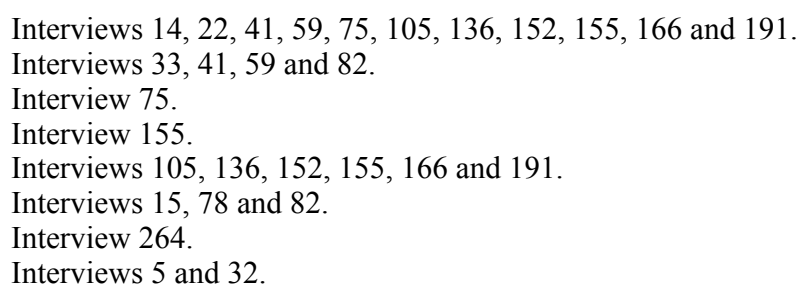


One tax law judge noted that the substance of cases does not affect him/her emotionally: 'I sleep no less at night.' ${ }^{9}$ Judges observed that cases seldom involve emotions, as migration or family law cases do. ${ }^{10}$

This chapter confirms that politico-strategic reasons continue to be relevant, but that their importance differs across courts and Member States. Some Dutch judges in particular acknowledged that politico-considerations may have played a (minor) role in the background when questioned more specifically about particular 'easy' cases during the interviews. The courts referred such relatively simple or clair cases to ask the ECJ to confirm what they already knew. ${ }^{11}$ The ECJ often does so by disposing of the reference in a three-judge formation without an AG opinion. This chapter will discuss the three dominant politico-strategic perspectives on the reference procedure: the shield (section 2), the sword (section 3) and leapfrogging (section 4). It will complement this with two explanations that have received little attention in the literature to date: the instrumental use of the ECJ as a transnational arbiter (section 5) and the desire to put a particular issue on the EU agenda through a reference (section 6).

\section{REFERENCE PROCEDURE AS SHIELD}

The research found limited support for the theory that courts deliberately shield cases from the ECJ and protect national legislation against the (further) expansion of EU law. ${ }^{12}$ There are two notable exceptions. First, the Criminal Chamber of the Dutch Supreme Court takes a reserved approach to the reference procedure. Second, a similar feeling among UK courts partly accounts for several decisions not to refer. A recent empirical study also found some support for the reluctance of judges to send 'unnecessary cases' in order to prevent the ECJ from expanding the reach of EU law. ${ }^{13}$ Mayoral and Pérez reported similar 'europhobia' among Spanish civil judges, who place great value on the ancient Spanish Civil Code. ${ }^{14}$ The previously discussed phenomenon of feedback loops plays a role in shield cases (Chapter 8, section 1.4): the reluctance of national courts to refer the cases discussed in this section was partly based on previous negative experiences with the ECJ and frustration about its heavily teleological approach.

\footnotetext{
Interview 51.

Interviews 78 and 82.

Cf van Gestel and de Poorter 2019, 75.

Alter 1998, 242.

Interview with a Swedish judge, Leijon and Glavina 2020.

Mayoral and Pérez 2018, 728.
} 
The Criminal Chamber of the Dutch Supreme Court is the first exception to the rule that the shield logic does not really guide the courts. Claassen found that criminal judges of the Supreme Court are wary of the growing influence of EU legislation and the ECJ. They consider criminal law a sovereign issue that should be regulated nationally - not least because the EU legislature and the ECJ are considered unable to oversee the practical consequences of their decisions. One judge suggested that bringing criminal procedural law within the EU's competence opens up a Pandora's box. Another judge noted the limited competence of the ECJ in relation to criminal law as a hindering factor. ${ }^{15}$ One example of this reluctance is the decision not to refer a question about the right to legal assistance during a police interrogation discussed in Chapter 2 (section 3.5). The Supreme Court explicitly stated, as a reason for this decision, that a reference precludes 'an effective and expeditious' criminal justice system. ${ }^{16}$ The limited use of the preliminary reference procedure by the Criminal Chamber is also a reason why the Dutch Chamber for International Cooperation frequently refers questions on the Framework Decision on the EAW (section 4.3).

The shield logic in the UK essentially boils down to feelings among judges that the ECJ is 'an unacceptable source of jurisprudence' and 'not one of us' ${ }^{17}$ Earlier research by Littlepage based on interviews with UK judges found that several UK judges hold such views. UK judges have been critical of the sometimes activist and intrusive nature of ECJ case law. ${ }^{18}$ Some UK judges even pointed to a 'systematic dismantling' of the common law of conflict of laws. ${ }^{19}$ Lord Mance observed that English common law is 'treading a path of its own, losing touch with that of its old pupils'; while some even questioned whether common law can survive at all. ${ }^{20}$ One UK judge pointed out that Factortame received a lot of criticism, not least because it suggested that the EU legal system is 'stronger than our own'. ${ }^{21}$ Lady Justice Arden criticized the ECJ for producing judgments which require profound changes to UK law and practice, thus increasing the workload for institutions and courts. ${ }^{22}$ She pointed to the 'ever-more pervasive' jurisprudence of the ECJ that 'does not sit easily with

\footnotetext{
Three interviewed judges, Claassen 2022.

Salduz NL:HR:2015:3608.

Littlepage 2014, 204; Interview 276.

George 1990; Jupile and Caporaso 2009; Barnard 2019.

9 Cf Hartley's article entitled 'The European Union and the systematic dismantling

of the common law of conflict of laws' as referred to by Mance $2013 \mathrm{~b}$.

20 Littlepage 2014, 222-23.

21 Interview 208.

22 Arden 2010, 9.
} 
our own domestic law', and criticized 'some ill-fitting and largely unnecessary principles ... [which are] superimposed on' the UK legal system. ${ }^{23}$

Implicit in much of this criticism are misgivings about the ECJ's heavily teleological approach. The reliance on principles in particular upsets common law lawyers, who attach significant weight to the view of the legislature. ${ }^{24}$ One UK judge criticized the ECJ's interpretation methods and dealings with travaux préparatoires, and cautioned that 'purposive construction is a dangerous beast'. ${ }^{25}$ Another UK judge pointed out that the ECJ is more 'politically driven' than would be acceptable to UK judges, since it acts almost as a federal court and pushes for greater integration. ${ }^{26} \mathrm{~A} \mathrm{UK}$ barrister voiced concern over 'an overexpansive interpretation' of the Citizens' Rights Directive. ${ }^{27}$ It is unsurprising that such concerns have been voiced in the UK, given the strong doctrine of parliamentary sovereignty and the strong adherence and faithfulness to the intention of the legislature. ${ }^{28}$ Ignoring this - as the ECJ has 'inappropriately' done in cases such as Mangold (on the applicability of general principles of EU law) and Sturgeon (on air passenger rights) - has upset UK common law lawyers. ${ }^{29}$ Lord Mance mentioned other problematic areas where this has happened, such as the development of criminal jurisdiction in relation to the environment and the case law on the Brussels I Regulation. ${ }^{30}$

These views of UK judges are not entirely unjustified. Danish academic Rasmussen pointed to a 'strong and bold pro-Community policy preference' back in $1986 .{ }^{31}$ Empirical research has also shown that ECJ judges not only 'speak the law', but also include considerations of policy, strategy and power in their decision making. ${ }^{32}$ The ECJ has not been slow to rule in way that is a diametrically opposed to the financial or political interests of Member States, and has used indeterminate provisions of EU law to deliver pro-integration judgments. ${ }^{33}$ Scholars have warned of the negative effects of this integration bias and heavily teleological approach on the perceived independence and impartiality, and hence the legitimacy, of the ECJ. ${ }^{34}$ Rasmussen highlighted

Ibid, $4-5$.

Ibid, 9; Mance 2013b; Laws 2014, 63.

Interview 264.

Interview 231; Sarmiento and Weiler 2020.

Interview 243. Cf Martinsen 2011.

Wind et al 2009, 77.

Interview 264. Cf Schmidt 2006; Schriek 2006.

Mance 2011, paras 2-4; Mance 2013a, paras 50-52, 55 and 57.

Rasmussen 1986, 17.

32 Mancini 1989; Garrett et al 1998; Alter 1998; de Waele 2009; Martinsen 2011;

Malecki 2012; Solanke 2011; Frankenreiter 2018; Ovádek 2020.

33 Cichowski 2007, 246.

34 Arnull 2013; Pollack 2018. 
the 'revolting judicial behaviour' and 'goal oriented' judgment of Van Gend en Loos, declaring that the direct effect of EU law had negative implications for the legitimacy of the ECJ. ${ }^{35}$ This criticism is voiced much less frequently in the Netherlands and Ireland; ${ }^{36}$ although some Dutch judges nonetheless recognize the problem. For example, in the interviews, one Dutch Supreme Court judge observed that the ECJ continually strives to opt for 'maximum options' and the supremacy of EU law principles, even in cases where less far-reaching options were also available. ${ }^{37}$

Concerns about the ECJ's handling of references have made the UK courts less eager to refer and have sometimes led to a desire to shield particular cases from the ECJ. ${ }^{38}$ One former UK Supreme Court judge pointed to the difficulty of being obliged to refer while not liking the anticipated answer. He/she admitted that this had happened once or twice in quite principled cases, without mentioning further details of those cases ${ }^{39}$ One UK barrister also discussed a case in which he/she spent four days in court poring through the case law of the ECJ. There was a consensus among the Court of Appeal judges and the parties that a reference should be avoided, given the low quality of the ECJ case law. The ECJ was said to have 'made stuff up' and 'invent[ed] what is not in the Directive'. ${ }^{40}$ Golub has also pointed out that the UK courts withheld references in the area of planning in the 1990s because references would lead to much stricter environmental standards. ${ }^{41}$

A prime illustration of this is the Supreme Court's decision not to refer in HS2, about a high-speed rail network (Chapter 2, section 3.6). This case essentially touched on the primacy of the UK Parliament and the possibility to review acts of the legislature. One factor that dissuaded a reference in $H S 2$ was past experience of the ECJ overstepping the jurisdictional limits laid down in the EU Treaties. ${ }^{42}$ Lord Neuberger and Lord Mance voiced explicit criticisms of the ECJ's creative interpretation, which diverged from the intentions of the

\footnotetext{
35 Rasmussen 1986, 12-13.

36 However, one Irish judge (128) was critical of the growing importance of the Charter and cases such as Bauer (C-569/16 Bauer EU:C:2018:871) from the perspective of the separation of and democratic legitimacy.

37 Interview 41.

38 Cf Arnull 2010, 79 and 81.

39 Interview 231.

40 Interview 243. Cf Bayer plc \& Anor v NHS Darlington CCG \& Ors [2020]

EWCA Civ 449, para 283.

${ }_{41}$ Golub 1996, 378-79.

42 Lord Mance in Pham v SSHD [2015] UKSC 19, para 90.
} 
EU legislature, thus damaging the democratic legitimacy of EU law and the principle of legal certainty. ${ }^{43}$ The Supreme Court held in rather bold terms:

Where the legislature has agreed a clearly expressed measure, reflecting the legislators' choices and compromises in order to achieve agreement, it is not for courts to rewrite the legislation, to extend or 'improve' it in respects which the legislator clearly did not intend. ${ }^{44}$

A second case that was deliberately withheld from the ECJ is Miller. The UK Supreme Court decided that the UK government can trigger Article 50 TEU upon withdrawal from the EU on the basis of a parliamentary act. Arnull observed rather aptly that it was obviously not very attractive to involve a supranational institution of an organization that the UK intended to leave. ${ }^{45}$ One barrister interviewed likewise suggested that not a single Supreme Court in the EU would refer such a case, because it was 'too close to home'. ${ }^{46}$ Another decision not to refer that can be explained on the basis of the shield logic is Chester, which concerned the voting rights of prisoners. ${ }^{47}$ One barrister thought that the Supreme Court deliberately decided not to refer because the case was too political in nature, exemplified by the heated political discussions following the famous judgments of the ECtHR in Hirst. ${ }^{48}$ The Supreme Court delivered Chester shortly before the ECJ ruled in Delvigne that EU law and the Charter apply to elections for the European Parliament. The Supreme Court nonetheless held that it was clair that EU law did not apply, since this was a matter for national parliaments. This barrister thought that the Supreme Court knew what the answer would be, but did not wish to have this answer because it would be counterproductive to have the ECJ make a decision that was contrary to the wish of the UK Parliament, especially at times when Euroscepticism was on the rise. ${ }^{49}$ A fourth prominent example is Stott, in which disagreement with the ECJ case law on the Montreal Convention 1999 dissuaded the Supreme Court from referring. ${ }^{50}$ The UK Supreme Court refused to accept a passenger's claim for damages for breach of violations under the Disability Regulation (1107/2006) because this would contravene the

\footnotetext{
43 Reed 2014, 10.

44 HS2 Action Alliance Ltd, $R$ (on the application of) $v$ The Secretary of State for Transport \& Anor [2014] UKSC 3, para 171.

45 Arnull 2017, 335.

46 Interview 243.

47 Chester, $R$ (on the application of) $v$ The Secretary of State for Justice (Rev 1)

[2013] UKSC 63, para 69. Konstadinides and Karatzia 2020, 505-06.

${ }_{48}$ Hirst v United Kingdom (No. 2) CE:ECHR:2005:1006JUD007402501.

49 Interview 211.

50 Arnull 2017, 332.
} 
Montreal Convention. According to one judge, the ECJ had gone 'mad' and was 'seriously wrong' in construing the Montreal Convention as being part of EU law. This judge referred to this as 'ridiculous and absurd'. The Supreme Court thus determined the scope and effect of EU law itself and emphasized that the Montreal Convention does not form part of EU law 'merely because the Convention takes effect via the Montreal Regulation'. ${ }^{51}$ Other UK courts have at times adopted a similar shield logic. Lady Justice Arden seemed to hint at disagreement with the ECJ over the Zambrano case law about the rights of residence of third-country nationals with minor children who are EU citizens as a reason for non-referral in Sanneh. She underlined that it is up to the Member States, and not the ECJ, to determine the level of social assistance for Zambrano carers who are in need and unable to work. She suggested that another reference would be pointless, because the ECJ had already 'declined a clear invitation' to reconsider its approach to reverse discrimination in Zambrano. ${ }^{52}$

One explanation for the shield logic adopted by some UK judges, as Lady Justice Arden argued, is the absence of constitutional review in the UK. This leads to an impression that 'constitutional decisions' are imposed from the outside, without any consideration by a national court. ${ }^{53}$ This explanation fits nicely with Wind's work on Scandinavian courts and their reluctance to refer because a culture of judicial review is largely absent from the region. ${ }^{54} \mathrm{By}$ contrast, Ireland has a solid 'home-grown' constitutional and fundamental rights tradition, with the possibility for judicial review dating back to $1937 .{ }^{55}$ Court decisions were responsible for seven of the 29 constitutional amendments. ${ }^{56}$ While constitutional review is prohibited in the Netherlands, there is a rich and extensive practice of review on the basis of international treaties because of the open, monist constitutional system. ${ }^{57}$

A second possible explanation for shield behaviour is the pressure of public opinion and domestic politics. ${ }^{58}$ At first sight, it seems plausible that the

Stott v Thomas Cook Tour Operators Ltd [2014] UKSC 15, para 50; Reed 2014. Sanneh \& Ors $v$ SSWP [2015] EWCA Civ 49, paras 128-29 and 131.

Arden 2010, 19. Cf Fusco 2015, 1531.

Wind 2010.

Interviews 159 and 162.

Egie et al 2018, 88.

Article 94 of the Dutch Constitution provides: 'Statutory regulations in force within the Kingdom shall not be applicable if such application is in conflict with provisions of treaties or of resolutions by international institutions that are binding on all persons.' Article 120: 'The constitutionality of Acts of parliament and treaties shall not be reviewed by the courts.'

58 Golub 1996, 377; Alter 1998, 236. 
reluctance of UK courts can be attributed to popular sentiment. ${ }^{59}$ However, it is difficult to find solid empirical support for this supposition based on a legal analysis of UK judgments. No judgments were found in which this was mentioned as a factor. The UK judges interviewed also argued that popular sentiment makes no difference to their behaviour; one stated that 'we simply have a duty to apply the law'. ${ }^{60}$ An exception mentioned in the interviews was the Chester case on prisoner voting rights: one judge noted that it is always possible, albeit necessarily difficult, to say that public opinion may have a subconscious impact on judicial thinking when deciding whether to refer. ${ }^{61}$ There is also an awareness among (some) UK judges of the popular sentiment vis-à-vis European courts. Lord Mance, for example, noted in a speech that 'European courts and law seem to become a target of sections of the press' ${ }^{62}$

Nor has the 2016 Brexit referendum had a major impact, despite allegations to this effect in the literature. ${ }^{63}$ The Supreme Court judges interviewed rejected the suggestion that Brexit was a factor in decisions (not) to refer. One judge insisted that the UK courts remain willing to refer ${ }^{64}$ Another noted that the Supreme Court has tried to avoid the implications of Brexit ('we just jumped around it').${ }^{65}$ These views are confirmed by the fact that the UK Supreme Court referred a VAT case on 1 April 2020 without considering the appropriateness to refer in light of the UK's departure from the EU on 31 January $2020 .{ }^{66}$ Furthermore, the Westminster Magistrates Court that deals with EAW cases submitted its first-ever reference in November 2020. ${ }^{67}$ The High Court saw Brexit as a reason to refer quickly in some cases, because the Court of Appeal would no longer be in a position to refer after Brexit. ${ }^{68}$ Only one High Court

\footnotetext{
Volcansek 1986, 206 and 217; Golub 1996, 377.

Interviews 231 and 264.
}

Interview 264.

Mance 2013b.

63 Dyevre et al 2019 found on the basis of a quantitative analysis that UK courts made 22 per cent fewer references after the Brexit referendum in 2016. One barrister (243) nonetheless mentioned that the drop in references in recent years was a 'Brexit thing', but noted at the same time that this has been a trend over the last ten years.

${ }^{64}$ Interview 264. Cf Coal Staff Superannuation Scheme Trustees Ltd v HMRC [2017] UKUT 137 (TCC), para 26.

65 Interview 231.

66 Zipvit Ltd v HMRC [2020] UKSC 15.

$67 \mathrm{https}: / /$ crucible.law/news/laura-herbert-secures-first-ever-reference-to-the-ECJ -from-magistrates-court.

68 Eli Lilly and Co v Genentech, Inc [2019] EWHC 388 (Pat), paras 47 and 50. The ECJ declared this 'pre-emptive' request inadmissible because of the hypothetical nature of the reference, C-239/19 Eli Lilly and Company EU:C:2019:687, para 26. Beverly Hills Teddy Bear Co v PMS International Group plc [2019] EWHC 2419 (IPEC), para 61. 
decision was found in which the fact that the UK would no longer be a Member State at the time of the ECJ judgment was cited as a factor not to refer. ${ }^{69}$

In sum, this section has shown that, in addition to the Criminal Chamber of the Dutch Supreme Court, the UK courts have likewise been reluctant to refer and have shielded particular cases from ECJ interference. This can be attributed to a strong commitment to upholding the intention of the legislature and the doctrine of parliamentary sovereignty, as well as resistance to the dynamic interpretations of the ECJ. The UK courts' reluctance to refer is also based on their negative experiences with the ECJ - an issue that will be further discussed in Chapters 5 and 6.

\section{REFERENCE PROCEDURE AS SWORD}

Another politico-strategic motivation for decisions to refer is the empowerment thesis: courts refer in order to challenge a national law or practice, with the aim of securing the support of the ECJ to increase the chance of government compliance with an eventual court ruling. There have been very few sword references in the three countries studied since 2013. This corresponds to the findings of Pavone, who showed that sword references are also rare in the Italian (lower) courts. ${ }^{70}$ One exception documented in the literature, and mentioned in Chapter 1, is the field of consumer law, where the lower Spanish, Slovak and Hungarian courts have been particularly eager to promote legislative change. ${ }^{71}$ Spanish Judge Seijo, who referred Aziz, saw no other alternative than to become an activist and provide a lifeline to stricken consumers during the economic crisis. The reference was a deliberate strategy: Seijo had been awaiting a suitable case that would allow him to take steps to address the interplay between Spanish law and the housing crisis. ${ }^{72}$

In interviews, Dutch, Irish and UK judges insisted that they did not need support from Luxembourg and could persuade the domestic authorities based on their own judgments. They would 'dare' to strike down provisions of national law themselves, because of their independence. ${ }^{73}$ Irish and UK judges in particular vehemently rejected the notion of a sword reference. This is somewhat surprising, given that this reasoning is evident in the older literature on the UK. ${ }^{74}$ One UK judge considered the sword thesis to be a 'very timid view

Tomanovic \& Ors v The European Union [2019] EWHC 263 (QB), para 93.

Pavone 2018.

Cafaggi 2017, 237-38.

Mayoral and Pérez 2018, 730 and 732.

Interviews 15, 23, 30, 41, 51, 59, 75, 87, 231.

4 According to scholars, the option of referring has - in the past at least - been used by the UK courts as an 'escape-valve' to avoid having to exercise a policy-making 
of judicial activity'. He/she held that it is unthinkable that the UK Supreme Court 'lacks authority' and is 'frightened' to declare legislation incompatible with EU or human rights law. ${ }^{75}$ The current UK Supreme Court also rejected the suggestion that the empowerment logic plays a role, stating in response to this question: '[T]here is no basis in the Supreme Court's case law for the suggestion that it has used the reference procedure, or been more likely to use the reference procedure, in order to "force" the legislature to do anything. " One Irish judge similarly insisted: 'I am prepared to make hard decisions... I am not a slimy little bug: it is not up to the ECJ to do my job.' Another asserted: 'I do not need cover or a fig leaf.' 77 The Irish courts are unafraid to determine that Irish law is in breach of the Constitution; finding that there has been a violation of the EU Treaties is little different. ${ }^{78}$ The Irish judiciary is considered to be among the most activist judiciaries in the world; court decisions were found to have prompted seven of the 29 amendments to the Irish Constitution. ${ }^{79}$

Some sword references have been made, however, especially in the Netherlands. Two types of 'sword' references may be discerned. First, 'pure' sword references aim to bring about legislative change or secure support from the ECJ for a particular interpretation of EU law. Second, references are made out of precaution due to the far-reaching societal, economic or political consequences of a particular judgment; courts are generally more cautious in such cases. ${ }^{80}$ One UK judge mentioned, on his/her own initiative, the case of O'Brien, which concerned the pensions of part-time, fee-paid judges. He/she noted that this case was also politically sensitive because it involved a great deal of public money. This was one factor that played a role in the decision to refer ${ }^{81}$ For the Dutch Supreme Court, the considerable consequences for pharmaceutical companies and consumers constituted an additional reason to refer in Antroposana and ACI Adam. ${ }^{82}$ The Central Appeals Tribunal referred questions with notable financial consequences about the exportability of particular

role that would deviate from their traditional respect for parliamentary sovereignty.

Levitsky 1994, 360 and 363; Nicola 2017, 1534; King 2015.

75 Interview 264.

76 Written response 15 April 2020.

77 Interviews 136 and 144. Cf Interviews 108, 128, 148 and 187.

78 Interviews 128, 152, 155 and 159. Eg Ryanair Ltd v Terravision Londen Finance Ltd [2011] IEHC 244 (Hogan J); see also recently Friends of the Irish Environment $v$ The Government of Ireland \& Ors [2020] IESC 49.

79 Egie et al 2018.

80 Interviews 44,87 and 243.

81 Interview 208.

82 De Staat v Antroposana NL:HR:2006:AU5271 (Case C-84/06 Antroposana and Others EU:C:2007:535); ACI ADAMv Stichting de Thuiskopie NL:HR:2012:BW5879 (Case C-435/12 ACI Adam and Others EU:C:2014:254). 
social allowances. ${ }^{83}$ The dividing line between the first and second category of sword references is not easy to make. The main difference relates to the way in which judges spoke about those cases. With respect to the first category, aimed at bringing about legislative change, judges spoke in terms of 'support' and 'shifting the blame'; whereas with respect to the second category, of precautionary references, judges primarily relied on legal and pragmatic arguments. ${ }^{84}$

The Dutch Chamber for International Cooperation of the Amsterdam District Court has made several 'pure' sword references. This Chamber is responsible for the execution of EAWs. One judge and legal secretary of the Chamber openly admitted that some references clearly aimed to bring about changes to the Dutch Surrender Act. They argued that the answers to several of the questions posed to the ECJ were clear, but that the Dutch legislature had a different perspective and that the Act was in breach of EAW Framework Decision (2002/584). In their view, a reference has clear added value because an ECJ judgment cannot be ignored ${ }^{85}$ The Chamber, for example, asked the ECJ about the conformity of a provision in the Dutch Surrender Act that makes surrender pursuant to an EAW subject to the condition that the act for which the arrest warrant was issued be punishable by a custodial sentence of at least 12 months in the Netherlands ${ }^{86}$ The underlying idea of this provision is to prevent surrender in 'small' cases with a low level of punishment. The Chamber decided to refer even though it was more or less clair that this requirement was inconsistent with EU law. ${ }^{87}$ This is illustrated by the fact that the ECJ decided the issue by way of an Order in just 23 days. As this example illustrates, sword references often aim to elicit the ECJ's confirmation of what the referring court already knows with respect to an issue that is in fact clair. ${ }^{88}$

In other sword references that have been made by the Dutch highest administrative courts, the Council of State was essentially 'hiding behind the back' of the ECJ and asking the ECJ to 'pull the chestnuts out of the fire' ${ }^{89}$ In Betfair, the Council of State entertained doubts about the conformity of the closed licensing system for gambling with EU law. ${ }^{90}$ Infringement proceedings in this regard were pending against the Netherlands and it was felt that the

83 Eg NL:CRVB:2005:AT9540 (Case C-287/05 Hendrix EU:C:2007:494); NL: CRVB:2007:BB7475 (Case C-485/07 Akdas and Others EU:C:2011:346); Interview 66.

Interviews 59 and 87.

Glerum and Klomp 2019.

Case C-463/15 PPU A. EU:C:2015:634.

NL:RBAMS:2015:5422, para 5.4; Glerum 2013, 317-22 and 357.

Cf van Gestel and de Poorter 2019, 75.

Interviews 10, 12, 18 and 44.

Case C-203/08 Betfair EU:C:2010:307. 
Council would find itself in a difficult position if the ECJ found a violation without any reference having been made. A similar example is the Chakroun case, which concerned the requirement for family reunification that sponsors have an income equal to at least 120 per cent of the minimum wage in order to be able to maintain their families. ${ }^{91}$ It was quite clear to the Council of State that this requirement violated the Family Reunification Directive. Indeed, the field of migration law has given rise to several strategic references. A more recent example concerned a reference of the District Court of The Hague on the conformity of the Dutch return policy for unaccompanied minors with the Return Directive and the protection of the best interests of the child as laid down in Article 24 of the Charter of Fundamental Rights. ${ }^{92}$ The single judge who referred this case pointed to the vulnerability of unaccompanied minors and stated that the discriminatory treatment on the basis of age for minors under the age of 15 was not allowed on the basis of EU law. She also implicitly criticized the Council of State for not having referred a question about this earlier, because the matter was definitively not clair or éclairé in her view. ${ }^{93}$

A reference provides support from Luxembourg not only towards the legislature, but also towards the executive. Wagenborg is a good illustration of this. The case concerned the grant of a concession for ferry services to the Dutch Wadden Islands without a competitive award procedure. Some judges of the Trade and Industry Appeals Tribunal were quite certain about the interpretation of EU law, but they sought a 'helping hand' from the ECJ because the responsible minister had taken a firm position during the proceedings to justify the grant of the concession. ${ }^{94}$ In a similar vein, the Central Appeals Tribunal felt forced to refer in Fischer-Lintjens. ${ }^{95}$ The Dutch authority responsible for health insurance had 'rigidly' adhered to its cancellation of healthcare insurance resulting from the retroactive withdrawal of the certificate of non-insurance. In its order for reference, the Tribunal hinted at the undesirability of this policy in light of the principle of legal certainty. One judge interviewed admitted that the Tribunal had 'used' the ECJ to say what it wanted to say itself, but with more authority.

It is perhaps unsurprising that administrative courts have made most of these sword references. The judges in these courts generally think more in political terms and are more focused on the legislature and the executive. ${ }^{96}$ One private law exception is Massar, in which the Supreme Court asked whether

\footnotetext{
Case C-578/08 Chakroun EU:C:2010:117.

Case C-441/19 TQ EU:C:2021:9.

NL:RBDHA:2019:5967, paras 39-41.

NL:CBB:2013:BZ6922, para 5.2.

Case C-543/13 Fischer-Lintjens EU:C:2015:359.

Interviews 41, 43, 59 and 66.
} 
the Legal Expenses Insurance Directive also applied to procedures before the Employee Insurance Agency in which an employer requests authorization to dismiss an employee. ${ }^{97}$ The Supreme Court order for reference explicitly mentioned the considerable financial consequences of a positive answer to this question. ${ }^{98}$ One judge acknowledged that the Supreme Court already knew the answer - namely, that the costs are covered - and was simply asking the ECJ to 'tick the box'. ${ }^{99}$ The ECJ did so, more or less, because it handled the case in a three-judge formation without an AG opinion. The Dutch judges considered it better to have the ECJ decide the matter and 'take the consequences' or provide 'an alibi', because they were aware that insurance policy costs would rise if the answer were positive. The following quote is illustrative: '[I]f that's what the EU wants, then it should be the EU that says it. That way, it wasn't us who came up with it.' ${ }^{100}$ It was thus wise to ask a preliminary question in order to 'make a potential time bomb harmless in advance', as one judge put it. ${ }^{101}$

However, too much value should not be attached to these ex-post rationalizations, which were not brought up by interviewees on their own initiative. Criticisms could be made about a strategic reading of several of these referrals. The decisions to refer in these cases could equally have a purely legal explanation, as some judges suggested: for example, some Dutch judges argued that in cases where there is considerable substantive 'counteraction' from the executive or the legislature, this simply confirms that there is doubt over the interpretation of EU law and there is no acte clair. ${ }^{102}$ Some judges noted that, in the case of democratically adopted laws, a judge should not make decisions light-heartedly, but only after careful deliberation, including in the light of the principle of the separation of powers. ${ }^{103}$ One Dutch Supreme Court judge disagreed with the strategic reading of Massar and simply held that doubt existed in this case as it concerned a disputed matter on which interpretations could reasonably differ. ${ }^{104}$ One UK judge likewise held that when an issue is politically contested, this simply shows that there a divergence of views, and that the legal issues involved are not as clear as one may think. ${ }^{105}$

This section has shown that the UK and Irish courts see no need to make sword references to obtain the ECJ's support vis-à-vis the legislature

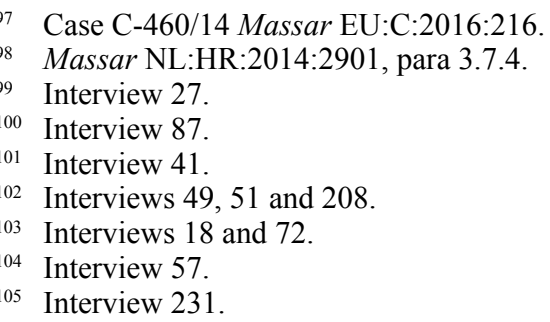


and executive. However, the Dutch highest administrative courts and the Chamber for International Cooperation have sometimes done so. This section highlighted another category of sword reference employed by other courts, whereby far-reaching societal, economic or political consequences serve as an additional driver for courts to refer, in order to be on the safe side.

\section{LEAPFROGGING THE JUDICIAL HIERARCHY}

The third politico-strategic perspective, on leapfrogging, posits that (lower) courts refer in order to bypass the national judicial hierarchy and secure support from the ECJ as protection against the reversal of their decisions by a higher court. The prevalence of leapfrog cases mirrors the situation described in the previous section regarding sword references. While leapfrog cases are almost non-existent in the UK and Ireland, there have been some instances of such cases in the Netherlands, especially in the area of migration law.

The leapfrog thesis has been discredited by judges in Ireland and the UK as 'very unusual', not least because lower courts feel bound by the decisions of the highest court (Chapter 3, section 2.1). ${ }^{106}$ Arnull observed that the UK Supreme Court is not subject to inter-court competition. ${ }^{107}$ The current UK Supreme Court also subscribed to this view and stated, in response to a question:

The case law of other UK courts in making references to the ECJ does not support the view that they have done so with the motive of leapfrogging the national judicial hierarchy in order to secure support from the ECJ for a particular outcome. ${ }^{108}$

One former UK Supreme Court judge noted that this is very much an Italian, German or French phenomenon - jurisdictions in which the lower courts tend to disagree more often with the highest court(s). By contrast, the UK system is considered homogeneous and coherent, and does not suffer from any distrust among the lower courts - not least due to the strong doctrine of precedent. The same judge further observed that there is a voluntary element to this: that is, a strong feeling that courts think in a similar way. ${ }^{109}$ Two UK barristers agreed and suggested that the strong system of precedent makes the lower courts reluctant to change the law; instead, they leave this to the higher or highest courts. ${ }^{110}$ Another barrister likewise noted that the lower courts adhere firmly to the judicial hierarchy. He/she attributed this to career considerations

106 Interviews 208 and 231.

107 Arnull 2017, 355.

108 Written response 15 April 2020.

109 Interview 264.

110 Interview 243, 276. 
- that is, judges are anxious to 'not [rock] the boat' and avoid being seen as 'radical' in order to enhance their prospects of promotion. According to him/ her, all judges harbour ambitions of an appointment to the Supreme Court, where the brightest of judges end up. They would thus prefer to showcase their intellectual rigour rather than undermining the Supreme Court. In addition, he/she pointed out that in the UK, there is no 'Germanic' division between a Constitutional and Supreme Court; or competition between the highest courts, as in France with the Cassation Court and the Council of State. ${ }^{111}$

The interviews are corroborated by the legal analysis, which confirmed the lower courts' adherence to the system of precedent and respect for the judicial hierarchy. In Ireland and the UK, no leapfrog cases were found in which a lower court bypassed the Supreme Court. Only very rarely has a lower court determined explicitly that another (higher) court wrongfully failed to refer. ${ }^{12}$ By contrast, quite a few judgments were found in which courts declined to refer because another (higher) court had previously decided not to refer similar questions. ${ }^{113}$ Judges feel bound by Supreme Court judgments in which a point of EU law was decided without a reference. The Irish Court of Appeal, for example, held:

having regard to the hierarchical system of our legal system and the importance of precedent in that legal system, it would be inappropriate for this Court to take a step which might be thought indirectly to impeach the authority of Olsson by making an Article 267 reference to the Court of Justice. ${ }^{114}$

The UK Court of Appeal also reasoned along similar lines and held that it was not justifiable to refer where the Supreme Court had very recently decided against referral in relation to the same question. ${ }^{115}$

111 Interview 211.

112 The Upper Tribunal noted in its reference that the Court of Appeal had incorrectly determined that there was an acte clair, C-544/18 Dakneviciute EU:C:2019:761; HMRC v HD [2018] UKUT 148 (AAC); Hrabkova v SSWP [2017] EWCA Civ 794.

$113 \mathrm{Eg}$ Catt, $R$ (on the application of) $v$ Brighton and Hove City Council \& Ors [2009] EWHC 1639 (Admin), para 14; Teshome v The Lord President of the Council [2014] EWHC 1468 (Admin); SET Select Energy GmbH $v$ F and M Bunkering Ltd [2014] EWHC 192 (Comm); L v M (Rev 1) [2019] EWHC 219 (Fam); Megantic Services Ltd v HMRC [2015] UKFTT 120 (TC), para 27; Ewart, Re Application for Judicial Review [2019] NIQB 88 (Keegan J), para 71.

114 Cf Interview 102: 'If there was no previous Supreme Court decision not to refer, I would have sent it away'. Minister for Justice and Equality $v$ O'Connor [2015] IECA 227 (Ryan P), para 34; $T v L$ [2015] IECA 363, para 47.

115 Eg Tolley (Deceased) v SSWP [2013] EWCA Civ 1471; Sanneh \& Ors v SSWP [2015] EWCA Civ 49 (Arden LJ), paras 125-26. 
The situation is different in the Netherlands, albeit only slightly. Some Dutch lower courts have made references in order to 'leapfrog' the national legal hierarchy and have the ECJ correct the jurisprudence of the highest court, particularly in the field of migration, as well as for EAWs. However, there have been (almost) no leapfrog references in other areas of law. ${ }^{116}$ A judge and legal secretary of the Chamber for International Cooperation dealing exclusively with EAWs even stated explicitly that all references to the ECJ aim to secure 'back cover' from the ECJ vis-à-vis the Supreme Court, preventing the latter from quashing judgments of the Chamber. ${ }^{117}$ The Chamber is well aware of the risk that the Criminal Chamber of the Supreme Court could decide a case without a reference, given its reluctance to refer (section 2). By referring earlier, the ECJ instead of the Supreme Court has the last word.

Four of the five migration law references of the Dutch lower courts in the period 2013-16 can be (partly) explained from this perspective. ${ }^{118}$ The Middelburg District Court, for example, challenged the Council of State's interpretation of Article 27(2) of the Citizens' Rights Directive with its reference in $K{ }^{119}$ An older example is $Y S$, which concerned the right of access of asylum seekers to the minutes of the Immigration and Naturalization Service. The single-judge section of the Middelburg District Court explicitly questioned the Council's restrictive interpretation of 'personal data' in the sense of the Data Protection Directive. ${ }^{120}$ The prevalence of leapfrogging in migration cases can be attributed to the more limited trust and confrontational relationship between the lower migration courts and the Council of State. ${ }^{121}$ It also relates to the influence of moral or ethical considerations in migration law. One 'activist' judge, for example, acknowledged that his/her need to refer would be less significant if the highest court were 'good'. This judge opined of the Council of State: 'For a long time I have had a bad taste of what it is doing in relation to EU law. That is why I would like to refer.' ${ }^{122}$ Another judge stated: 'We did not want an answer from the Council of State. The Council has been consciously passed over.' He/she added that the latter would be a 'dead-end route'. ${ }^{123}$ The Council of State has been challenged not only by the lower

\footnotetext{
116 One tax law exception is Joined Cases C-72/14 and C-197/14 X and Van Dijk EU:C:2015:564.

117 Glerum and Klomp 2019.

118 Case C-550/16 A and S EU:C:2018:248; Case C-331/16 K EU:C:2018:296; Case

C-63/15 Ghezelbash EU:C:2016:409; C-158/13 Rajaby EU:C:2013:455.

119 NL:RBDHA:2016:6389, para 19.

120 NL:RBMID:2012:BV8942, para 9.

121 Interview 51.

122 Interview 39.

123 Van Alphen 2017, 21.
} 
courts, but also by its administrative counterpart, the Tribunal, albeit more indirectly. In Chavez Vilchez, the Tribunal questioned the Council's restrictive reading of Zambrano, giving mothers a right of residence derived from the right of residence of their children. ${ }^{124}$ The Council applied Zambrano only to situations in which the father was not in a position to care for the child. ${ }^{125}$

In conclusion, the Dutch lower migration courts and the Chamber for International Cooperation handling EAWs have at times used the preliminary reference procedure to leapfrog the hierarchy and to challenge a(n expected) restrictive interpretation of EU law by the highest court. By contrast, there is considerably more respect for the judicial hierarchy in the UK and Ireland. This section has confirmed that the importance of the leapfrog phenomenon should not be exaggerated. ${ }^{126}$

\section{USING THE ECJ AS A TRANSNATIONAL ARBITER}

The ECJ's authority is not only sought in internal conflicts with the legislature, executive or other courts; in other scenarios, it is sought to resolve a transnational conflict with other courts or to prevent conflicts from arising - not least with a view to ensuring the uniformity of EU law. The Tax Chamber of the Dutch Supreme Court has referred several customs cases for this reason. The question in these cases was frequently under which tariff heading of the Combined Nomenclature a particular product was to be classified. One example is Sonos, which concerned a wireless music system. Some interviewees questioned whether a reference was necessary in this case because the district and appeal court had reached the same conclusion regarding the tariff heading, which was further supported by the AG of the Supreme Court. ${ }^{127}$ These references are often dealt with by the ECJ in a three-judge chamber formation without the Opinion of an $\mathrm{AG}$, suggesting that the questions are relatively straightforward or even clair. The Supreme Court judges interviewed nonetheless dismissed the suggestion that the court did not 'dare' to decide these cases itself. ${ }^{128}$ The problem is that if the Supreme Court answers

\footnotetext{
124 NL:CRVB:2015:665, para 4.2; Case C-133/15 Chavez-Vilchez EU:C:2017:354; Case C-34/09 Zambrano EU:C:2011:124.

125 NL:RVS:2013:2837.

126 A French Supreme Administrative Court judge stated that the French lower courts look to the case law of the Council of State and are not likely to disregard this when they expect the ECJ to rule differently. Van Gestel and de Poorter 2019, 123.

127 Interview 35; NL:HR:2015:285 (C-84/15 Sonos EU:C:2016:184); NL:HR:2015: 221 (C-97/15 Sprengen EU:C:2016:556).

128 Interview 30.
} 
the question itself and classifies the product, it may do so in a different way from the courts in other EU Member States. Where it chooses a more disadvantageous classification for the undertaking(s) concerned, this could end up disrupting trade flows and distorting competition. ${ }^{129}$ The Supreme Court is thus careful in its approach to customs cases and prefers to refer to Luxembourg so that 'the whole of Europe knows where we stand', thereby guaranteeing the uniform application of EU law. ${ }^{130}$ Interviewees realized that the law-making character is limited in most of these cases, and that they do not pertain to fundamental aspects of the EU legal order. ${ }^{131}$ This explained, in their view, why most of these references are handled by the ECJ without an AG Opinion. ${ }^{132}$

Several references of the Chamber for International Cooperation responsible for the execution of EAWs were also made with this objective in mind. One judge and legal secretary acknowledged that the Chamber referred some questions where the answer was clear to it; a reference was nonetheless considered necessary given the differing interpretations in other EU Member States. Such judicial authorities would not (easily) accept the Chamber's interpretation of EU law; they would be more likely to do so on the basis of an ECJ judgment. This could also explain why there have been many similar references by various courts - including Irish and UK courts - on the notion of 'issuing judicial authority' in the EAW Framework Decision. ${ }^{133}$ The Central Appeals Tribunal also used the preliminary reference procedure to resolve a difference in opinion with a German court in Mertens. ${ }^{134}$ This case concerned Mertens' right to unemployment benefits. He had worked in Germany while living just across the border in the Netherlands. The Tribunal had tried to contact the German court before which Mertens had appealed the German refusal to grant unemployment benefits, with the aim of arriving at a coordinated solution. However, the German judge declined to do so and was unwilling to discuss individual pending cases because of privacy considerations. ${ }^{135}$ According to some interviewees, the case was fairly simple from a legal perspective. The Tribunal also stated clearly in its order for reference that it was obvious that Germany was obliged to grant the benefits. ${ }^{136}$ The ECJ decided accordingly in a three-judge formation without an AG opinion. It needed only 15 paragraphs

\footnotetext{
129 Interviews $15,33,78$ and 82.

130 Interview 78.

131 Interviews 15, 30 and 33.

132 Ibid.

133 Eg Joined Cases C-508/18 and C-82/19 PPU OG and PI EU:C:2019:456; Case C-206/20 VA v Bulgaria.

134 Case C-655/13 Mertens EU:C:2015:62.

135 NL:CRVB:2013:2665, para 3.10.

136 Ibid, paras 3.8-3.9.
} 
to do so, in which it referred extensively to its previous case law, thereby suggesting that the matter was clair. The Central Appeals Tribunal thus secured the desired ECJ authority.

There are also examples of the transnational arbiter phenomenon in Ireland and the UK. As discussed in Chapter 2, section 3.4, the UK courts in particular have referred some cases to the ECJ to ensure the uniformity of EU law and hence to prevent transnational conflicts with the authorities in other EU Member States. In the copyright case of Public Relations Consultants Association, Lord Sumption seemed to recognize that 'sufficient guidance is available', but noted that a reference was nonetheless desirable. He pointed to 'a transnational dimension' and held that copyright law in relation to internet use has consequences for virtually everyone in the EU, warranting the involvement of the ECJ so that the outcome would apply uniformly across the EU. ${ }^{137}$ Just as in the Dutch customs cases, the ECJ answered without an AG opinion, thus suggesting that the answer to the question was indeed relatively clair. The referral of the Irish Court of Appeal in the child abduction case of Hampshire County Council also falls into this category. Rather than issuing an order against the UK public authority, the problem was 'passed' to Luxembourg, because it would have greater impact 'to have Europe adjudicate' it than an Irish court. ${ }^{138}$ The ECJ 'gives comfort' in such a situation. ${ }^{139}$

\section{PUTTING AN ISSUE ON THE EUROPEAN AGENDA}

Another politico-strategic consideration that has sometimes played a role is the wish to put a particular issue or concern on the European agenda. ${ }^{140}$ Interviewed judges admitted that the reference of the Civil Chamber of the Dutch Supreme Court in Diageo Brands had a 'political undertone'. ${ }^{141}$ In this case, the Supreme Court wondered whether it was obliged to enforce a Bulgarian judgment on the basis of the principle of mutual trust if there was reason to assume that the judgment was in breach of EU law. One judge held that, by referring this case to Luxembourg, attention was drawn to the problem of the limited independence of the judiciary in some Member States. The referral might thus contribute to the rule of law and thus even to peace and security

\footnotetext{
137 Public Relations Consultants Association Ltd $v$ The Newspaper Licensing Agency Ltd \& Ors [2013] UKSC 18 (Sumption LJ), para 39.

138 Interview 148; Joined Cases C-325/18 PPU and C-375/18 PPU Hampshire County Council EU:C:2018:739.

139 Interview 166.

140 Bogojevíc 2017, 273; Thym 2012, 212.

141 Diageo Brands NL:HR:2013:2062; Interview 27.
} 
in Europe. ${ }^{142}$ The Dutch Tax Chamber similarly referred questions about the conformity of a tax deduction scheme of study costs for people under the age of 30 with the prohibition against age discrimination in the Equal Treatment Directive (2000/78). ${ }^{143}$ An additional motivation was to put a broader question on the agenda - that is, the extent to which the directive applies to all kinds of tax regulations. Before this point was raised, this Directive had barely featured in tax practice. ${ }^{144}$ Another Dutch Supreme Court judge noted that the issue of whether to refer in the Holterman Ferho case arose partly from a 'legal gut feeling' that employee protection should prevail. ${ }^{145}$

An Irish judge also acknowledged that his/her reference regarding the EAW system aimed to put this issue on the agenda and ultimately to simplify the system. He/she expressed his/her 'disappointment' and 'extreme frustration' that since its introduction in 2004, the EAW process had become 'turgid', with 'a huge amount of delays'. He/she stated:

if you can clarify one issue common to a number of cases that are likely to recur, than you assist the processes. Maybe it also informs the Commission. Or it is a reason to look at the Framework Decision again. ... it is about improving knowledge... let's get it sorted out. ${ }^{146}$

Several references of UK High Court Judge Birss also seem to fall within this category. He made three references in six months about the Regulation concerning SPCs for medicinal products. In one reference, Judge Birss pointed to 'the dysfunctional state of the SPC system' flowing from the 'poor drafting' of the Regulation and the failure of the EU legislature to address these problems. ${ }^{147}$ Nine of the 14 references made by former UK High Court Judge Arnold also concerned the SPC. He attributed this to the simplistic drafting of EU legislation in relation to SPCs. ${ }^{148}$

\section{CONCLUSION}

This chapter has downplayed the relevance of politico-strategic considerations, but has shown that these motives play a role in particular areas of law or for some courts, such as the Dutch lower migration courts and the Dutch Chamber

\footnotetext{
142 Interview 59.

143 Case C-548/15 De Lange EU:C:2016:850.

144 Interview 30.

145 Holterman Ferho NL:HR:2014:164; Interview 27.

146 Interview 187.

147 GlaxoSmithKline Biologicals SA v Comptroller-General of Patents, Designs and Trade Marks [2013] EWHC 619 (Pat) (Birss J), para 86.

148 Arnold 2020, 1105.
} 
for International Cooperation in relation to EAWs. What most of these cases have in common is that they were often decided by the ECJ with a three-judge formation and without an AG Opinion. This suggests that the legal issue was relatively clair, and that the referring court simply asked the ECJ to confirm what it already knew itself. The sword and leapfrog logic have been almost absent from the UK and Ireland; while the Criminal Chamber of the Dutch Supreme Court and the UK courts have sometimes shielded references from the ECJ. The logic behind the unwillingness to refer particular cases is to prevent a too far-reaching interpretation of EU law from affecting the constitutional set-up and parliamentary sovereignty. This chapter has pointed to two other categories of politico-strategically inspired references that have received limited attention in the literature: the desire to involve the ECJ as a transnational arbiter to resolve particular conflicts or to ensure the uniform application of EU law; and the desire to bring particular problems in EU legislation and its application to the attention of the ECJ or the EU legislature. 